Article

\title{
Acute Oral Toxicity Evaluations of Some Zinc(II) Complexes Derived from 1-(2-Salicylaldiminoethyl)piperazine Schiff Bases in Rats
}

\author{
Muhammad Saleh Salga ${ }^{1, *}$, Hapipah Mohd Ali ${ }^{1}$, Mahmood Ameen Abdulla ${ }^{2}$ and \\ Siddig Ibrahim Abdelwahab ${ }^{3}$
}

1 Department of Chemistry, University of Malaya, Kuala Lumpur 50603, Malaysia; E-Mail: hapipah@um.edu.my

2 Department of Molecular Medicine, University of Malaya, Kuala Lumpur 50603, Malaysia; E-Mail: mahmood955@yahoo.com

3 Department of Pharmacy, University of Malaya, Kuala Lumpur 50603, Malaysia; E-Mail: siddigroa@um.edu.my

* Author to whom correspondence should be addressed; E-Mail: salgamohd@yahoo.com; Tel./Fax: +60-126155723.

Received: 22 December 2011; in revised form: 12 January 2012 / Accepted: 13 January 2012 / Published: 27 January 2012

\begin{abstract}
The current study described the synthesis and the in vivo acute oral toxicity evaluations in Sprague Dawley rats. The compounds were characterized by elemental analyses, LC-MS, FTIR, ${ }^{1} \mathrm{H}$ NMR, ${ }^{13} \mathrm{C}$ NMR and UV-visible spectroscopy. In the acute toxicity study, a single administration of the compounds was performed orally to the rats at the single doses of $2000 \mathrm{mg} / \mathrm{kg}$ and they were then monitored for possible side effects, mortality or behavioral changes up to 14 days. The serum level of aspartate (AST), alanine aminotransferases (ALT), alkaline phosphate (ALP), triglyceride, high density lipoprotein (HDL), immunoglobulins (GAM) and the C-reactive proteins did not significantly change. The hematological indices white blood cells (WBC), haematocrit (HCT), red blood cells (RBC), mean corpuscular volume (MCV), mean corpuscular haemoglobin concentration (MCHC), and mean corpuscular hemoglobin $(\mathrm{MCH})$ were within the normal range. The renal function indices examined were also within the reference range. Generally, the compounds exhibited low toxic effects as required for further in vivo therapeutic studies.
\end{abstract}

Keywords: synthesis; characterizations; acute toxicity; zinc complexes 


\section{Introduction}

Zinc has been shown to play an important role in wound healing, proper functioning of mucosal cells, reduction of reactive oxygen species (ROS) [1] and as a cofactor for metallo-enzymes [2]. Zinc deficiency or excess can lead to many metabolic disorders such as growth retardation, decreased spermatogenesis, dysgeusia, anosmia and anemia to meat, eggs, liver and oysters. Several studies were performed to determine the mechanisms for zinc balance and the effects of zinc excess on iron metabolism [3] with much emphasis on small molecular weight metal binding proteins [4]. Despite the biological importance of zinc, the safety of its compounds in many dietary supplements has remained an issue of debate. However, the interaction of zinc ions with certain Schiff base ligands has been studied due to their relevance in bio inorganic chemistry. For example, they form carbon-nitrogen bonds [5], which make them important intermediates in a number of enzymatic reactions [6-8]. Polydentate ligands, on the other hand, have been reported to exhibit potential activities in removing the undesirable effect of metal ion by deactivating either the carcinogenic metal or the enzyme required in order to protect the cells. The activities of various ligands were reported to have increased upon coordination with the metal ions; therefore, studies on novel metal-based compounds with therapeutic potential became an area of intense investigation in biomedical and inorganic chemistry [9-12]. However, metal ions are generally toxic at a high-dose level; therefore, to study the therapeutic potential of novel metal-based compounds; the acute toxicity level must first be evaluated. Moreover, the compounds containing piperazine moiety were reported to have shown various biological activities in many studies $[13,14]$ and, specifically, the Schiff bases derived from piperazine compounds have been described to demonstrate various biological activities; for example, anthelmintic [15], antimicrobial [16,17], acetylcholinesterase inhibition [18], melanocortin-4-receptor (MC4-R) [19,20], drug designer [21] anti-PAF [22,23], anti-HIV [24,25] and anti-obesity [26] activities. However, the literature reveals no report on their toxicity class. This, therefore, prompted the present study to synthesize, characterize and evaluate for the first time the acute oral toxicity of some novel zinc(II) complexes derived from some 1-(2-salicylaldiminoethyl) piperazine Schiff bases.

\section{Result and Discussion}

\subsection{Chemistry}

The reaction of 2-(piperazin-1-yl)ethanamine with some selected aldehydes resulted in the formation of the corresponding 1-(2-salicylaldiminoethyl)piperazines Schiff bases. The prepared Schiff bases (Scheme 1) were used to synthesize the novel complexes of zinc (II) chloride (Scheme 2). The compounds exhibited MS, NMR, IR and UV-Visible spectra consistent with the proposed structures which allowed the synthesized compounds to be recognized as 2-((2-(piperazin-1-yl)ethylimino) methyl)phenol-dichlorido-Zn-(II). [Zn(LSP)Cl $]$ ], 4-chloro-2-((2-(piperazin-1-yl)ethylimino)methyl) phenol-dichlorido-Zn-(II). [ $\left.\mathrm{Zn}(\mathrm{LCS}) \mathrm{Cl}_{2}\right]$, 4-bromo-2-((2-(piperazin-1-yl)ethylimino)methyl)phenoldichlorido-Zn-(II). [Zn(LBS) $\left.\mathrm{Cl}_{2}\right]$, respectively. 
Scheme 1. Reaction pathway for the Schiff bases.<smiles>NCCN1CCNCC1</smiles>

\section{LSP}<smiles>NCCN1CCNCC1</smiles>

LCS<smiles>NCCN1CCNCC1</smiles>

LBS

Scheme 2. Reaction pathway for zinc complexes.

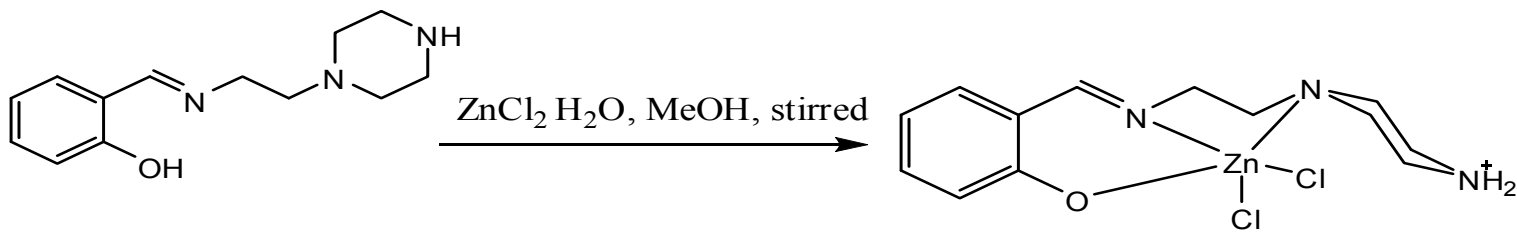

$\left[\mathrm{Zn}(\mathrm{LSP}) \mathrm{Cl}_{2}\right]$

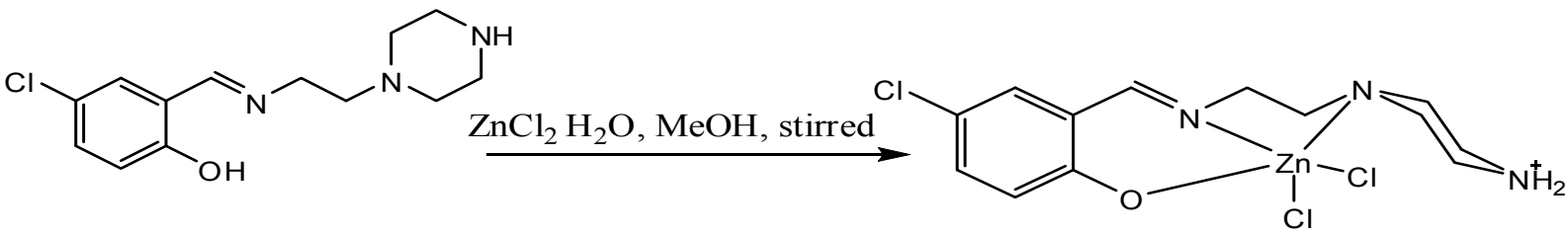

$\left[\mathrm{Zn}(\mathrm{LCS}) \mathrm{Cl}_{2}\right]$

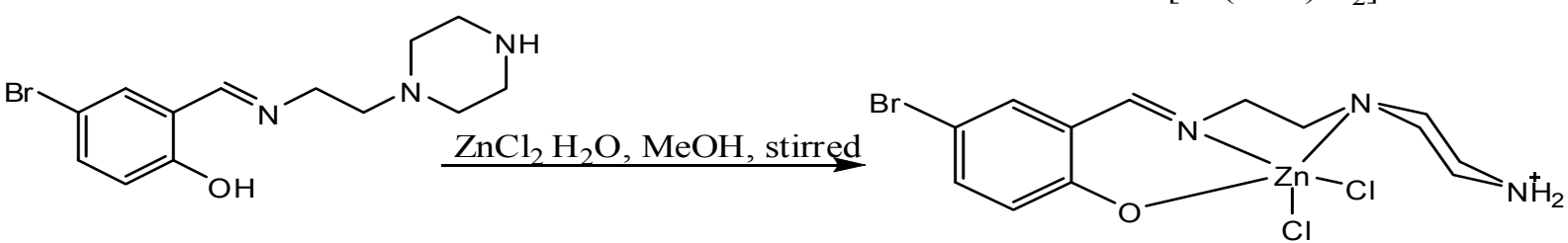

$\left[\mathrm{Zn}(\mathrm{LBS}) \mathrm{Cl}_{2}\right]$

The IR spectra of the complexes displayed band regions at the wavelengths of $1,628,1,624$, and $1631 \mathrm{~cm}^{-1}$ for $\left[\mathrm{Zn}(\mathrm{LSP}) \mathrm{Cl}_{2}\right],\left[\mathrm{Zn}(\mathrm{LCS}) \mathrm{Cl}_{2}\right]$ and $\left[\mathrm{Zn}(\mathrm{LBS}) \mathrm{Cl}_{2}\right]$, respectively, which could be due to the characteristic iminic frequency [27,28]. These bands appeared at $1636 \mathrm{~cm}^{-1}, 1631 \mathrm{~cm}^{-1}$ and $1616 \mathrm{~cm}^{-1}$ in the spectra of the free Schiff bases of the above-mentioned complexes correspondingly. In addition, the coordination of imine nitrogen to the zinc was further ascertained by the appearance of signal at the band regions $486 \mathrm{~cm}^{-1}, 581 \mathrm{~cm}^{-1}$ and $578 \mathrm{~cm}^{-1}$ in the spectra of the corresponding complexes due to $\mathrm{Zn}-\mathrm{N}$ bond [29] which is supported by the zinc-phenolate (Zn-O) [30] signals at $569 \mathrm{~cm}^{-1}, 645 \mathrm{~cm}^{-1}$ 
and $631 \mathrm{~cm}^{-1}$ respectively. The proton NMR is also consistent with the IR spectral data, where the imine-zinc coordination was observed at $7.92 \mathrm{ppm}, 8.02 \mathrm{ppm}$ and $8.05 \mathrm{ppm}$ in the spectra of $\left[\mathrm{Zn}(\mathrm{LSP}) \mathrm{Cl}_{2}\right],\left[\mathrm{Zn}(\mathrm{LCS}) \mathrm{Cl}_{2}\right]$ and $\left[\mathrm{Zn}(\mathrm{LBS}) \mathrm{Cl}_{2}\right]$, respectively. These signals initiated from $7.28 \mathrm{ppm}$, $7.53 \mathrm{ppm}$ and $7.68 \mathrm{ppm}$ in the spectra of the free Schiff bases of the corresponding complexes. This supposition was supported by the ${ }^{13} \mathrm{C}$ NMR spectra which showed imine carbon at $162.6 \mathrm{ppm}$, $164.2 \mathrm{ppm}$ and $165.2 \mathrm{ppm}$ respectively due to complexation. The phenolate carbon atoms also appeared at $161.5 \mathrm{ppm}, 159.5 \mathrm{ppm}$ and $158.4 \mathrm{ppm}$ in the respective order of the complexes mentioned above [31]. To further elucidate the structure of the complexes, UV-visible spectra were recorded using DMSO. The spectra of the complexes exhibited two absorption band maxima each at $279 \mathrm{~nm}$, $204 \mathrm{~nm}$ and $267 \mathrm{~nm}$ for $\left[\mathrm{Zn}(\mathrm{LSP}) \mathrm{Cl}_{2}\right],\left[\mathrm{Zn}(\mathrm{LCS}) \mathrm{Cl}_{2}\right]$ and $\left[\mathrm{Zn}(\mathrm{LBS}) \mathrm{Cl}_{2}\right]$ respectively. This could be afforded to the $\pi-\pi^{*}$ electronic transitions [32,33] the phenolic ring. The other absorptions noticeable to $351 \mathrm{~nm}, 362 \mathrm{~nm}$ and $382 \mathrm{~nm}$ can be due to ligand to metal charge transfer [34,35].

\subsection{Acute Toxicity Study}

The analysis of the toxicity level of chemical compounds is the most important step required for further biological studies [36]. The toxicity level of the zinc complexes derived from 1-(2-salicylaldiminoethyl)piperazines were evaluated at the maximum dose of $2000 \mathrm{mg} / \mathrm{kg} / \mathrm{body}$ weight. The compounds were administered orally to the $24 \mathrm{~h}$ fasted rats and monitored closely after every $30 \mathrm{~min}$ up to $8 \mathrm{~h}$ of post treatment. It was observed that the compounds did not cause any gross behavioral alterations like convulsion, dizziness or respiratory distress. No mortality was recorded for the period of 14 days, which indicate that the lethal dose of the compounds is above $2000 \mathrm{mg} / \mathrm{kg}$ body weight in rats and that the compounds can be considered to be less harm at this dose.

\subsection{Body and Organ Weight Changes}

The animals treated with the zinc complexes for two weeks had manifested an increase in body weight slightly above the animals in the control group (Figure 1). The target organs such as liver and kidney of both the control and the treatment group did not exhibit any change in color or texture, and the weight of these organs was not significantly $(P<0.05)$ affected by the zinc complexes (Figure 2$)$. This also demonstrated the less toxic effect [37] of the compounds. 
Figure 1. Effects of zinc complexes on the body weights.

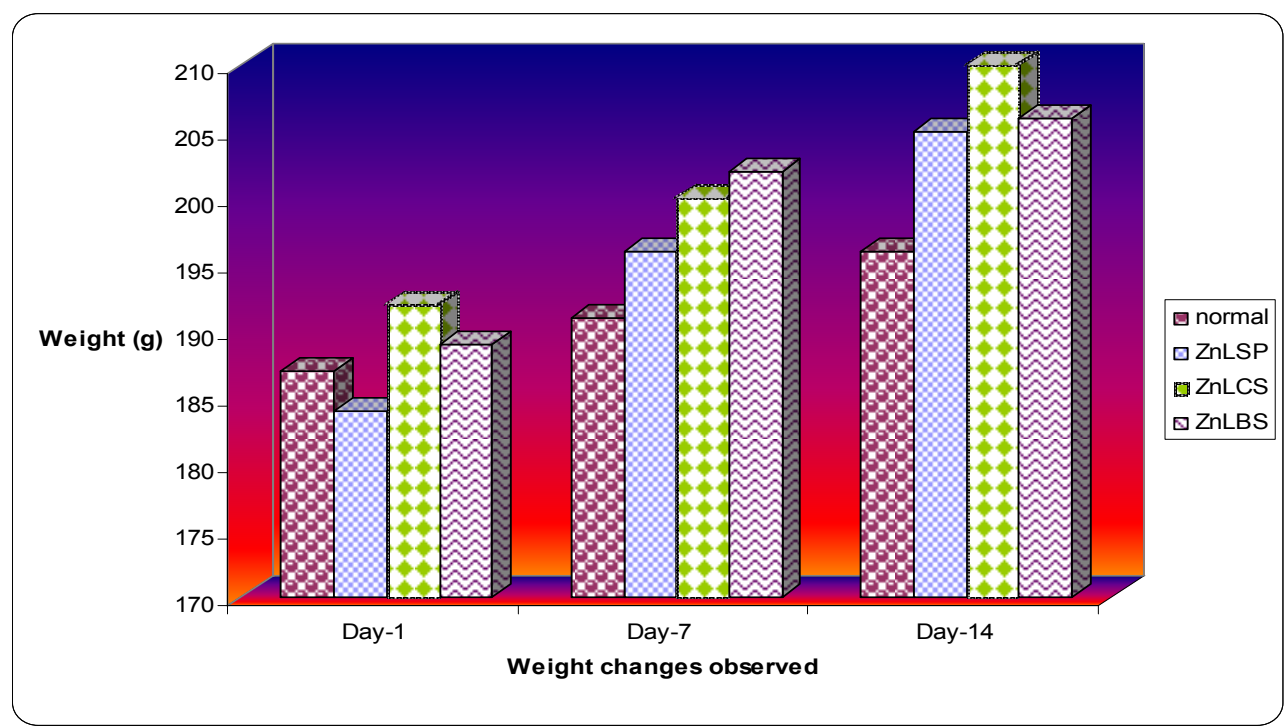

Figure 2. Effects of zinc complexes on the organ weights.

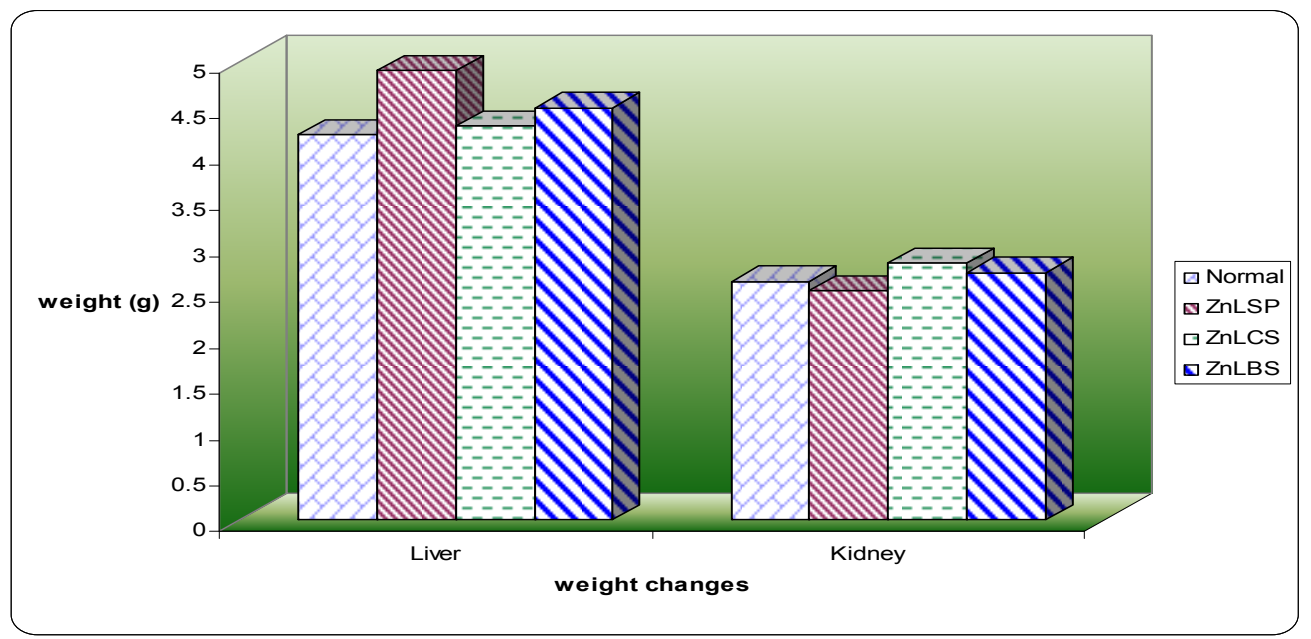

\subsection{Effects of Zinc Complexes on the Biochemical Indices}

The oral administration of the zinc complexes for two weeks did not cause any significant changes in the biochemical parameters such as renal function indices like creatinine, urea, anion gap sodium and carbon dioxide. Both the normal rats and the rats treated with zinc complexes had manifested the level of biochemical indices within the normal range (Table 1). However, the liver enzymes AST, ALT, ALP and triglyceride rose significantly in the rats that received ZnLSP, compared to the rats administered with the complexes ZnLCS and ZnLBS and the normal rats. This can be attributed to the damage in the liver cells [38] due to low toxic effect of the compounds. This is reduced in the analogue complexes that contained ring substituents in their structures, thus displaying the influence of ring substituents on the activity of the compounds [39,40]. Other liver indices like total protein count, albumin, globulins, total cholesterol, total and conjugated bilirubin did not significantly change at the dose of $2000 \mathrm{mg} / \mathrm{kg} /$ body weight (Table 2). A similar result was obtained in the acute toxicity evaluations of the free ligands in our previous study [27]. 
Table 1. Effect of zinc complexes on the renal functions.

\begin{tabular}{ccccc}
\hline Indices & Normal & {$\left[\mathbf{Z n}(\mathbf{L S P}) \mathbf{C l}_{2}\right]$} & {$\left[\mathbf{Z n}(\mathbf{L C S}) \mathbf{C l}_{2}\right]$} & {$\left[\mathbf{Z n}(\mathbf{L B S}) \mathbf{C l}_{2}\right]$} \\
\hline Sodium & $139.5 \pm 2.6$ & $139.2 \pm 2.4$ & $138.2 \pm 2.7$ & $138.5 \pm 2.9$ \\
Potassium & $5.05 \pm 0.8$ & $5.50 \pm 0.6$ & $4.70 \pm 0.9$ & $5.100 \pm 0.7$ \\
Chloride & $103.8 \pm 1.3$ & $104.6 \pm 2.3$ & $105.1 \pm 1.2$ & $102.3 \pm 1.7$ \\
$\mathrm{CO}_{2}$ & $23.9 \pm 2.1$ & $22.2 \pm 2.6$ & $21.3 \pm 3.2$ & $23.10 \pm 3.3$ \\
Anion gap & $17.4 \pm 1.2$ & $18.5 \pm 0.7$ & $16.5 \pm 3.1$ & $18.50 \pm 3.5$ \\
Urea & $6.10 \pm 1.3$ & $7.40 \pm 0.6$ & $7.60 \pm 1.7$ & $9.300 \pm 2.6$ \\
Creatinine & $42.5 \pm 1.9$ & $28.4 \pm 17$ & $40.8 \pm 1.9$ & $50.50 \pm 1.9$ \\
\hline
\end{tabular}

Table 2. Effects of zinc complexes on the liver functions.

\begin{tabular}{ccccc}
\hline Indices & Normal & {$\left[\mathbf{Z n}(\mathbf{L S P}) \mathbf{C l}_{2}\right]$} & {$\left[\mathbf{Z n}(\mathbf{L C S}) \mathbf{C l}_{2}\right]$} & {$\left[\mathbf{Z n}(\mathbf{L B S}) \mathbf{C l}_{2}\right]$} \\
\hline Total protein & $70.5 \pm 3.6$ & $87.3 \pm 4.9$ & $75.5 \pm 3.2$ & $81.8 \pm 2.6$ \\
Albumin & $59.5 \pm 2.4$ & $68.6 \pm 4.1$ & $62.5 \pm 3.2$ & $69.3 \pm 0.5$ \\
Globulin & $59.5 \pm 3.4$ & $69.5 \pm 4.9$ & $61.9 \pm 2.2$ & $65.3 \pm 2.4$ \\
Alk. Phosphate & $59.30 \pm 11.3$ & $81.30 \pm 10.8$ & $82.3 \pm 11.3$ & $92.80+12.5$ \\
ALT & $49.8 \pm 7.2$ & $61.0 \pm 3.6$ & $57.8 \pm 3.4$ & $55.3 \pm 4.9$ \\
AST & $259.8 \pm 12.7$ & $292.3 \pm 10.6$ & $278.5 \pm 9.8$ & $281.5 \pm 12.6$ \\
Total bilirubin & $6.25 \pm 0.5$ & $7.50 \pm 0.7$ & $6.88 \pm 0.8$ & $7.32 \pm 0.8$ \\
C.bilurubin & $3.61 \pm 0.9$ & $5.83 \pm 1.3$ & $3.85 \pm 1.4$ & $4.22 \pm 2.1$ \\
Triglyceride & $0.45 \pm 0.1$ & $0.60 \pm 0.4$ & $0.30 \pm 0.05$ & $0.80 \pm 0.8$ \\
Total cholesterol & $2.20 \pm 0.3$ & $3.70 \pm 0.5$ & $3.30 \pm 0.1$ & $3.60 \pm 0.4$ \\
HDL & $1.53 \pm 0.4$ & $1.47 \pm 0.2$ & $1.39 \pm 0.4$ & $1.50 \pm 0.6$ \\
\hline
\end{tabular}

The hematological profile of the rats treated with zinc complexes did not significantly differ in the red blood cell (RBC), mean corpuscular volume (MCV) and mean corpuscular hemoglobin (MCH). Furthermore, the values of the biomarkers like hematocrit (HCT), RDW and platelet in the treated rats are comparable with those in the normal rats, except the biomarker MCHC which showed inconsistent results in the treatment groups. However, for ZnLCS and ZnLBS, the values obtained are within the physiological ranges [41] for rats (Table 3). The value obtained for MCHC in the rats treated with the complex ZnLSP is below that of the normal rats and there is no interpretation from the literature for this.

Table 3. Effects of zinc complexes on the hematological indices.

\begin{tabular}{ccccc}
\hline Indices & Normal & {$\left[\mathbf{Z n}(\mathbf{L S P}) \mathbf{C l}_{\mathbf{2}}\right]$} & {$\left[\mathbf{Z n}(\mathbf{L C S}) \mathbf{C l}_{2}\right]$} & {$\left[\mathbf{Z n}(\mathbf{L B S}) \mathbf{C l}_{2}\right]$} \\
\hline HGB & $151.3 \pm 11.0$ & $162.3 \pm 11.8$ & $158.3 \pm 12.2$ & $163.3 \pm 13.5$ \\
HCT & $0.540 \pm 0.21$ & $0.980 \pm 0.03$ & $0.830 \pm 0.01$ & $0.920 \pm 0.04$ \\
RBC & $7.90 \pm 0.4$ & $8.10 \pm 0.3$ & $8.60 \pm 0.3$ & $8.80 \pm 0.7$ \\
MCV & $65.2 \pm 2.4$ & $69.3 \pm 1.5$ & $67.9 \pm 1.8$ & $76.9 \pm 1.8$ \\
MCH & $17.9 \pm 0.9$ & $18.1 \pm 0.3$ & $18.9 \pm 0.6$ & $18.6 \pm 0.5$ \\
MCHC & $291.2 \pm 2.3$ & $260.5 \pm 4.4$ & $302.3 \pm 5.6$ & $269.3 \pm 4.5$ \\
RDW & $15.8 \pm 1.4$ & $17.5 \pm 1.2$ & $16.6 \pm 1.5$ & $17.9 \pm 2.1$ \\
WBC & $10.7 \pm 3.1$ & $11.3 \pm 0.4$ & $12.9 \pm 4.4$ & $12.4 \pm 1.8$ \\
Platelet & $654.3 \pm 9.5$ & $846.6 \pm 8.5$ & $689.3 \pm 9.7$ & $708.3 \pm 9.4$ \\
\hline
\end{tabular}


The acute phase immunoglobulins' G, A and M, the complements 3 and 4, and the level of C-reactive protein did not significantly differ between the normal, and the treated rats in both gender. This indicates that the complexes did not interfere with the immune system of the treated rats [42] (Table 4).

Table 4. Effects of zinc complexes on the immunological indices.

\begin{tabular}{ccccc}
\hline Indices & Normal & {$\left[\mathbf{Z n}(\mathbf{L S P}) \mathbf{C l}_{2}\right]$} & {$\left[\mathbf{Z n}(\mathbf{L C S}) \mathbf{C l}_{\mathbf{2}}\right]$} & {$\left[\mathbf{Z n}(\mathbf{L B S}) \mathbf{C l}_{2}\right]$} \\
\hline ImmunoglobulinG & $933.4 \pm 2.3$ & $933.8 \pm 4.2$ & $933.5 \pm 3.6$ & $933.9 \pm 4.8$ \\
Immunoglobulin A & $97.5 \pm 2.2$ & $89.6 \pm 3.7$ & $98.7 \pm 4.4$ & $99.2 \pm 4.3$ \\
Immunoglobulin M & $43.9 \pm 7.9$ & $42.3 \pm 3.5$ & $52.7 \pm 8.3$ & $63.5 \pm 9.6$ \\
Complement 3 & $96.8 \pm 2.3$ & $96.2 \pm 1.2$ & $96.6 \pm 3.2$ & $96.9 \pm 1.7$ \\
Complement 4 & $29.8 \pm 2.1$ & $52.9 \pm 3.2$ & $57.2 \pm 4.2$ & $57.9 \pm 4.2$ \\
C-reactive Protein & $0.42 \pm 0.3$ & $0.34 \pm 0.5$ & $0.45 \pm 0.2$ & $0.53 \pm 0.2$ \\
\hline
\end{tabular}

\section{Experimental}

\subsection{Chemistry}

2-(piperazin-1-yl)ethanamine, salicylaldehyde, 5-chlorosalicylaldehyde, and 5-bromosalicylaldehyde were used without further purification. Methanol, absolute ethanol, dimethylsulfoxide (DMSO) and all other solvents were of analytical grade. Spectroscopic grade DMSO- $\mathrm{d}_{6}$ was used for ${ }^{1} \mathrm{H}$ and ${ }^{13} \mathrm{C}$ NMR. All the chemicals used were purchased from Sigma Aldrich (Kuala Lumpur, Malaysia) and used without further purification. Mass spectra were determined using ABI 4800 Maldi TOF/TOF mass spectrophotometer (BIDMC Genomics, Proteomics and Bioinformatics Core, Boston, MA, USA) (LC-MS, ESI, $125.0 \mathrm{~V}$ ); IR spectra was recorded at the wavelength range from $4000-400 \mathrm{~cm}^{-1}$ using a Perkin Elmer 783 spectrophotometer; NMR spectra was obtained on a ECA400 FT-NMR spectrophotometer using TMS as internal standard, UV-visible spectra was recorded on an UV-1650PC model UV-visible spectrophotometer.

\subsection{Schiff Bases}

The Schiff bases (LSP, LCS and LBS) were prepared according to the reported general procedure [43] described below with some modifications.

To the ethanolic solution $(25 \mathrm{~mL})$ of (2-piperazin-1-yl)ethanamine (2.58 g, $20 \mathrm{mmol})$, salicylaldehyde $(2.44 \mathrm{~g}, 20 \mathrm{mmol})$ taken in ethanol $(25 \mathrm{~mL})$ was added with stirring. The resulting solution was refluxed for three hours, cooled and concentrated to give a red gel. The gel became hygroscopic solid after seven days under vacuum. The solid product is then dissolved in methanol by heating to $55{ }^{\circ} \mathrm{C}$. While hot, few drops of diethyl ether were added and yellow solid appeared which was collected by filtration. Recrystallization was performed in ethanol-water mixture. The same procedure was followed in the preparation of LCS and LBS Schiff bases. 


\subsection{Complexes}

\subsubsection{2-((2-(piperazin-1-yl)ethylimino)methyl)phenol-dichlorido-Zn-(II): [Zn(LSP)Cl $\left.\mathrm{Cl}_{2}\right]$}

Stoichiometric amount of Zinc (II) chloride ( $0.14 \mathrm{~g}, 1 \mathrm{mmol})$ in methanol $(25 \mathrm{~mL})$, was added to an equimolar quantity of the appropriate Schiff base $(1 \mathrm{mmol})$ dissolved in the same solvent $(25 \mathrm{~mL})$ at room temperature and followed with few drops of potassium hydroxide. A yellow precipitate was produced upon stirring. The precipitate filtered, washed with distilled water and dried in the vacuum for further analysis. The same method was applied in the synthesis of $\left[\mathrm{Zn}(\mathrm{LCS}) \mathrm{Cl}_{2}\right]$ and $\left[\mathrm{Zn}(\mathrm{LBS}) \mathrm{Cl}_{2}\right]$. $\mathrm{C}_{13} \mathrm{H}_{18} \mathrm{Cl}_{2} \mathrm{~N}_{3} \mathrm{ZnO}$ : yield; (0.15 g 40.6\%). Anal. Cal. C, 66.9; H, 8.21; N, 18.01. Found: C, 65.82; H, 7.76; N, 17.97\%. m/z: 369.03, 367.04, 371.01. IR (KBr disc, 4000-400 $\mathrm{cm}^{-1}$ ) selected bands: $v(\mathrm{~N}-\mathrm{H}), 3442 ; v(\mathrm{C}-\mathrm{H})$ alip., 2825; $v(\mathrm{C}=\mathrm{N}), 1628 ; v(\mathrm{C}-\mathrm{C})$ arom., 1468; $v(\mathrm{C}-\mathrm{N}), 1152 ; v(\mathrm{C}-\mathrm{H})$ arom.768; $v(\mathrm{M}-\mathrm{O}), 569 ; v(\mathrm{M}-\mathrm{N}), 486 .{ }^{1} \mathrm{H}$ NMR (400 MHz, DMSO-d6) $\delta$ ppm: $7.92(\mathrm{~s}, 1 \mathrm{H},-\mathrm{C}=\mathrm{N}-)$; 2.66-3.45 (t, 2H, $\left.\mathrm{C}_{\text {aliph }}\right) ;{ }^{13} \mathrm{C}$ NMR (100 MHz, DMSO-d6) $\delta$ ppm: $46.5\left(\mathrm{CH}_{2}\right) ; 34.51\left(\mathrm{CH}_{2}\right) ; 36.5$ $\left(\mathrm{CH}_{2}\right) ; 39.4\left(\mathrm{CH}_{2}\right) ; 122.8(\operatorname{armC}) ; 161.5(\mathrm{CO}) ; 162.6(\mathrm{C}=\mathrm{N}) ; 117.6(\operatorname{armC}) ; 125.7$ (armC). UV-vis (DMSO), $\lambda_{\max }\left(\varepsilon, \mathrm{mol}^{-1} \cdot \mathrm{L} \mathrm{cm}^{-1}\right): 279 \mathrm{~nm}\left(2647.49, \pi-\pi^{*}\right), 351 \mathrm{~nm}(2811.20, \mathrm{LMCT})$.

\subsubsection{4-chloro-2-((2-(piperazin-1-yl)ethylimino)methyl)phenol-dichlorido- $\mathrm{Zn}(\mathrm{II})$ : $\left[\mathrm{Zn}(\mathrm{LCS}) \mathrm{Cl}_{2}\right]$}

$\mathrm{C}_{13} \mathrm{H}_{17} \mathrm{~N}_{3} \mathrm{Cl}_{3} \mathrm{O}_{2} \mathrm{Zn}$ : yield; (0.19 g, 47\%). Anal. Cal. C, 58.31; H, 6.78; N, 15.69. Found: C, 57.97; $\mathrm{H}$, 5.94; N, 15.27. m/z: 402.98, 400.98, 404.97. IR (KBr disc, 4000-400 $\mathrm{cm}^{-1}$ ) selected bands: $v(\mathrm{~N}-\mathrm{H}), 3459 ; v(\mathrm{C}-\mathrm{H})$ alp., 2966; $v(\mathrm{C}=\mathrm{N}), 1624 ; v(\mathrm{C}-\mathrm{C})$ arom., 1466; $v(\mathrm{C}-\mathrm{N}), 1172 ; v(\mathrm{C}-\mathrm{H})$ arom.704; $v(\mathrm{M}-\mathrm{O}), 645 ; v(\mathrm{M}-\mathrm{N}), 581 .{ }^{1} \mathrm{H}$ NMR (400 MHz, DMSO- $\left.d 6\right) \delta$ ppm: $8.02(\mathrm{~s}, 1 \mathrm{H},-\mathrm{C}=\mathrm{N}-)$; 2.56-3.48 (t, 2H, $\left.\mathrm{C}_{\text {aliph }}\right) ;{ }^{13} \mathrm{C}$ NMR (100 MHz, DMSO- $\left.d 6\right) \delta$ ppm: $45.6\left(\mathrm{~s}, 1 \mathrm{CH}_{2}\right) ; 34.8\left(\mathrm{~s}, 1 \mathrm{CH}_{2}\right)$; $34.9\left(\mathrm{~s}, 1 \mathrm{CH}_{2}\right) ; 123.2(\mathrm{~s}, 1 \mathrm{armCH} 2) ; 159.5(\mathrm{~s}, 1 \mathrm{CO}) ; 164.2(\mathrm{~s}, 1 \mathrm{C}=\mathrm{N}) ; 116.2\left(\mathrm{~s}, 1 \operatorname{armCH}_{2}\right) ; 123.6$ (s, $1 \mathrm{CH}_{2}$ ). UV-vis (DMSO), $\lambda_{\max }\left(\varepsilon, \mathrm{mol}^{-1} \mathrm{~L} \cdot \mathrm{cm}^{-1}\right): 204 \mathrm{~nm}\left(937.9, \pi-\pi^{*}\right), 326 \mathrm{~nm}(3989.7, \mathrm{LMCT})$

\subsubsection{4-bromo-2-((2-(piperazin-1-yl)ethylimino)methyl)phenol-dichlorido-Zn-(II): [Zn( $\left.\mathrm{LBS} \mathrm{Cl}_{2}\right]$}

$\mathrm{C}_{13} \mathrm{H}_{17} \mathrm{~N}_{3} \mathrm{BrCl}_{2} \mathrm{O}_{2} \mathrm{Zn}$ : yield; (0.32g 71.3\%). Anal. Cal. C, 34.89; H, 3.83; N, 9.39. Found: C, 34.82; $\mathrm{H}, 3.66$; N, 8. 98. m/z: 446.93, 448.93, 450.92. IR (KBr disc, 4000-400 $\mathrm{cm}^{-1}$ ) selected bands: $v(\mathrm{~N}-\mathrm{H}), 3448 ; v(\mathrm{C}-\mathrm{H})$ alp., 2966; $v(\mathrm{C}=\mathrm{N}), 1631 ; v(\mathrm{C}-\mathrm{C})$ arom., 1466; $v(\mathrm{C}-\mathrm{N}), 1169 ; v(\mathrm{C}-\mathrm{H})$ arom. ) 686; $v(\mathrm{M}-\mathrm{O}), 631 ; v(\mathrm{M}-\mathrm{N}), 578 .{ }^{1} \mathrm{H}$ NMR (400 MHz, DMSO- $\left.d 6\right) \delta$ ppm: $8.05(\mathrm{~s}, 1 \mathrm{H},-\mathrm{C}=\mathrm{N}-)$; 2.52-3.43 (t, 2H, $\left.\mathrm{C}_{\text {aliph }}\right) ;{ }^{13} \mathrm{C}$ NMR (100 MHz, DMSO-d6) $\delta$ ppm: $46.6\left(\mathrm{~s}, 1 \mathrm{CH}_{2}\right) ; 34.7\left(\mathrm{~s}, 1 \mathrm{CH}_{2}\right)$; $35.1\left(\mathrm{~s}, 1 \mathrm{CH}_{2}\right) ; 122.1\left(\mathrm{~s}, 1 \mathrm{CH}_{2}\right) ; 158.4(\mathrm{~s}, 1 \mathrm{CO}) ; 165.2(\mathrm{~s}, 1 \mathrm{C}=\mathrm{N}) ; 114.4\left(\mathrm{~s}, 1 \mathrm{CH}_{2}\right) ; 124.5$ (s, $\left.1 \mathrm{CH}_{2}\right)$. UV-vis (DMSO), $\lambda_{\max }\left(\varepsilon, \mathrm{mol}^{-1} \cdot \mathrm{L} \mathrm{cm}^{-1}\right): 267 \mathrm{~nm}\left(1939.17, \pi-\pi^{*}\right), 382 \mathrm{~nm}(1564.26, \mathrm{LMCT})$

\subsection{Animals}

Adult Sprague Dawley rats of 8-9 weeks old weighed 180-200 g were obtained from Animal House, Faculty of Medicine, University of Malaya (Kuala Lumpur, Malaysia). The animals were housed in animal room at temperatures $22 \pm 3{ }^{\circ} \mathrm{C}$ and $12 \mathrm{~h}$ dark period. After one-week acclimatization, rats were distributed into four groups of ten rats each (five males and five females, labeled as control and treated) and maintained on standard pellet food and purified drinking water. All 
animals received human care according to the criteria outlined in the "Guide for the Care and Use of Laboratory Animals" prepared by the National Academy of Sciences and published by the National Institute of Health.

\subsection{Acute Toxicity Test}

Acute toxicity evaluations were carried out on rats according to the reported method with some modifications [44]. Sprague Dawley rats of both genders were divided into experimental and control groups (10 rats per group of five males and five females each). The study was executed at a single oral dose of $2000 \mathrm{mg} / \mathrm{kg}$ body weight, in $5 \mathrm{~mL} / \mathrm{kg}$ volume. The control group was treated with distilled water. The experimental group was fasted for $24 \mathrm{~h}$ before the administration of the compound but allowed access to distilled water. The animals were further denied access to food for $2 \mathrm{~h}$ of post treatment in order to examine the possible adverse effects of the compounds such as behavioral adjustments, autonomous released of mucus, dizziness restlessness or mortality.

\subsection{Statistical Analysis}

The results were analyzed using one-way analysis of variance (ANOVA) and expressed as mean \pm SEM. Probability values of $P<0.05$ was considered statistically significant.

\section{Conclusion}

In conclusion, the results of this study showed that the zinc complexes derived from the Schiff bases 2-(2-(piperazin-1-yl)ethylimino)methyl)phenol, 4-chloro-2-(2-(piperazin-1-yl)ethylimino)methyl) phenol and 4-bromo- 2-(2-(piperazin-1-yl)ethylimino)methyl) phenol have fewer toxic effects based on the insignificant changes observed in the behavioral, hematological, immunological and biochemical parameters. However, a decrease in the activity of liver and some hematological indices was noted, which require further study to fully ascertain the safety of the compounds at high doses.

\section{Acknowledgement}

The author highly acknowledged the financial support given by the University of Malaya through the grants; PS358/2009C and ER009/2011A

\section{Reference}

1. Wintergerst, E.S.; Maggini, S.; Hornig, D.H. Immune-enhancing role of vitamin C and zinc and effect on clinical conditions. Ann. Nutr. Metab. 2006, 50, 85-94.

2. McCall, K.A.; Huang, C.; Fierke C.A. Function and mechanism of zinc metalloenzymes. J. Nutr. 2000, 130, 1437S-1446S.

3. O’Neil-Cutting, M.A.; Bomford, A.; Munro, H. Effect of excess dietary zinc on tissue storage of iron in rats. J. Nutr. 1981, 111, 1969-1979.

4. Barry, C.; Starcher, J.G.G.; Madaras, J.G. Zinc Absorption and Its Relationship to Intestinal Metallothionein. J. Nutr. 1980, 110, 1391-1397. 
5. Cruickshank, P.; Sheehan, J.C. Gas chromatographic analysis of amino acids as $N$-trifluoroacetylamino acid methyl esters. Anal. Chem. 1964, 36, 1191-1197.

6. Jacobus, W.E.; Lehninger, A.L. Creatine kinase of rat heart mitochondria. J. Biol. Chem. 1973, 248, 4803-4810.

7. Lehninger, A.L., Vercesi, A.; Bababunmi, E.A. Regulation of $\mathrm{Ca}^{2+}$ release from mitochondria by the oxidation-reduction state of pyridine nucleotides. Proc. Nat. Acad. Sci. USA 1978, 75, 1690-1694.

8. Vazquez, M.A.; Munoz, F.; Donoso, J.; Blanco, F.G. Spectroscopic study of the Schiff bases of dodecylamine with pyridoxal 5'-phosphate and 5'-deoxypyridoxal. A model for the Schiff bases of pyridoxal 5'-phosphate in biological systems. Biochem. J. 1991, 279, 759-767.

9. Salata, C.A.; Youinou, M.T.; Burrows, C.J. Preparation and structural characterization of dicopper (II) and dinickel (II) imidazolate-bridged macrocyclic Schiff base complexes. Inorg. Chem. 1991, 30, 3454-3461.

10. Dowling, C.; Murphy, V.J.; Parkin, G. Bis (pyrazolylethyl) ether ligation to zinc and cobalt: Meridional vs facial coordination and the suitability of such ligands in providing a NNO donor set for modeling bioinorganic aspects of zinc chemistry. Inorg. Chem. 1996, 35, 2415-2420.

11. Cohen, S.M. New approaches for medicinal applications of bioinorganic chemistry. Curr. Opin. Chem. Biol. 2007, 11, 115-120.

12. Rafique, S.; Idrees, M.; Nasim, A.; Akbar, H.; Athar, A. Transition metal complexes as potential therapeutic agents. Biotech. Mol. Biol. Rev. 2010, 5, 38-45.

13. Nishat, N.; Haq, M.M.; Ahamad, T.; Kumar, V. Synthesis, spectral and antimicrobial studies of a novel macrocyclic ligand containing a piperazine moiety and its binuclear metal complexes. J. Coord. Chem. 2007, 60, 85-96.

14. Keypour, H.; Rezaeivala, M.; Valencia, L.; Perez-Lourido, P. Synthesis and crystal structure of Mn (II) complexes with novel macrocyclic Schiff-base ligands containing piperazine moiety. Polyhedron 2008, 27, 3172-3176.

15. Islam, M.K.; Miyoshi, T.; Yamada, M.; Alim, M.A.; Huang, X.; Motobu, M.; Tsuji, N. Effect of piperazine (diethylenediamine) on the moulting, proteome expression and pyrophosphatase activity of Ascaris suum lung-stage larvae. Acta. Trop. 2006, 99, 208-217.

16. Chaudhary, P.; Kumar, R.; Verma, A.K.; Singh, D.; Yadav, V.; Chhillar, A.K.; Sharma, G.L.; Chandra, R. Synthesis and antimicrobial activity of $\mathrm{N}$-alkyl and $\mathrm{N}$-aryl piperazine derivatives. Bioorgan. Med. Chem. 2006, 14, 1819-1826.

17. Narendra, S.C.J.N.; Sadashiva, C.T.; Kavitha, C.V.; Rangappa, K.S. Synthesis and in vitro antimicrobial studies of medicinally important novel $\mathrm{N}$-alkyl and $\mathrm{N}$-sulfonyl derivatives of 1-[bis (4-fluorophenyl)-methyl] piperazine. Bioorg. Med. Chem. 2006, 14, 6621-6627.

18. Sadashiva, C.T.; Narendra, S.C.J.N.; Ponnappa, K.C.; Veerabasappa G.T.; Rangappa, K.S. Synthesis and efficacy of 1-[bis (4-fluorophenyl)-methyl] piperazine derivatives for acetylcholinesterase inhibition, as a stimulant of central cholinergic neurotransmission in Alzheimer's disease. Bioorgan. Med. Chem. Lett. 2006, 16, 3932-3936.

19. Nozawa, D.; Okubo, T.; Ishii, T.; Takamori, K.; Chaki, S.; Okuyama, S.; Nakazato, A. Novel piperazines: Potent melanocortin-4 receptor antagonists with anxiolytic-like activity. Bioorg. Med. Chem. 2007, 15, 2375-2385. 
20. Chen, C.; Jiang, W.; Tucci, F.; Tran, J.A.; Fleck, B.A.; Hoare, S.R.; Joppa, M.; Markison, S.; Wen, J.; Chen, C.W.; et al. Discovery of 1-\{2-[(1S)-(3-Dimethylamino-propionyl)amino-2methylpropyl]-4-methyl-phenyl $\}-4-[(2 R)$-methyl-3-(4-chlorophenyl)-propionyl] piperazine as an Orally Active Antagonist of the Melanocortin-4 Receptor for the Potential Treatment of Cachexia. J. Med. Chem. 2007, 50, 5249-5252.

21. Staack, R.F.; Paul, L.D.; Springer, D.; Kraemer, T.; Maurer, H.H. Cytochrome P450 dependent metabolism of the new designer drug 1-(3-trifluoromethylphenyl) piperazine (TFMPP): In vivo studies in Wistar and Dark Agouti rats as well as in vitro studies in human liver microsomes. Biochem. Pharmacol. 2004, 67, 235-244.

22. Serradji, N.; Bensaid, O.; Martin, M.; Sallem, W.; Dereuddre-Bosquet, N.; Benmehdi, H.; Redeuilh, C.; Lamouri, A.; Dive, G.; Clayette, P.; et al. Structure-activity relationships in platelet-activating factor. Part 13: Synthesis and biological evaluation of piperazine derivatives with dual anti-PAF and anti-HIV-1 or pure antiretroviral activity. Bioorg. Med. Chem. 2006, 14, 8109-8125.

23. Benmehdi, H.; Lamouri, A.; Serradji, N.; Pallois, F.; Heymans, F. Synthesis of new trisubstituted 4-aminopiperidines as PAF-receptor antagonists. Eur. J. Org. Chem. 2008, 2008, 299-307.

24. Sallem, W.; Serradji, N.; Dereuddre-Bosquet, N.; Dive, G.; Clayette, P.; Heymans, F. Structure-activity relationships in platelet-activating factor. Part 14: Synthesis and biological evaluation of piperazine derivatives with dual anti-PAF and anti-HIV-1 activity. Bioorg. Med. Chem. 2006, 14, 7999-8013.

25. Salga, M.S.; Ali, H.M.; Abdullah, M.A.; Abdelwahab, S.I.; Hussain, P.D.; Hadi, A.H.A. Mechanistic studies of the anti-ulcerogenic activity and acute toxicity evaluation of dichlorido-copper (II)-4-(2-5-Bromo-benzylideneamino) ethyl) piperazin-1-ium phenolate complex against ethanol-induced gastric injury in rats. Molecules 2011, 16, 8654-8669.

26. Yu, M.; Lizarzaburu, M.; Beckmann, H.; Connors, R.; Dai, K.; Haller, K.; Li, C.; Liang, L. Lindstrom, M.; Ma, J.; et al. Identification of piperazine-bisamide GHSR antagonists for the treatment of obesity. Bioorg. Med. Chem. Lett. 2010, 20, 1758-1762.

27. Salga, S.M.; Ali, H.M.; Abdullah, M.A.; Abdelwahab, S.I.; Wai, L.K.; Buckle, M.J.C.; Sukumaran, S.D.; Hadi, A.H.A. Synthesis, characterization, acetylcholinesterase inhibition, molecular modeling and antioxidant activities of some novel schiff bases derived from 1-(2ketoiminoethyl) piperazines. Molecules 2011, 16, 9316-9330.

28. Nath, M.; Saini, P.K.; Kumar, A. New di-and triorganotin (IV) complexes of tripodal Schiff base ligand containing three imidazole arms: Synthesis, structural characterization, anti-inflammatory activity and thermal studies. J. Organomet. Chem. 2010, 695, 1353-1362.

29. Yuan, R.; Chai, Y.; Liu, D.; Gao, D.; Li, J.; Yu, R. Schiff base complexes of cobalt (II) as neutral carriers for highly selective iodide electrodes. Anal. Chem. 1993, 65, 2572-2575.

30. Holm, R.H. Studies on Ni (II) complexes. I. Spectra of tricyclic schiff base complexes of Ni (II) and $\mathrm{Cu}$ (II). J. Am. Chem. Soc. 1960, 82, 5632-5636.

31. Cimerman, Z.; Galesic, N.; Bosner, B. Structure and spectroscopic characteristics of Schiff bases of salicylaldehyde with 2,3-diaminopyridine. J. Mol. Struct. 1992, 274, 131-144.

32. Vlcek, A. Mechanistic roles of metal-to-ligand charge-transfer excited states in organometallic photochemistry. Coord. Chemi. Rev. 1998, 177, 219-256. 
33. Koester, V.J. Interligand transmetallic charge-transfer transitions in mixed-ligand chelates. Chem. Phys. Lett. 1975, 32, 575-580.

34. Zalis, S.; Farrell, I.R.; Vlcek, A., Jr. The involvement of metal-to-CO charge transfer and ligand-field excited states in the spectroscopy and photochemistry of mixed-ligand metal carbonyls. A theoretical and spectroscopic study of [W (CO) 4(1,2-ethylenediamine)] and [W (CO) 4 (N,N'-bis-alkyl-1,4-diazabutadiene)]. J. Am. Chem. Soc. 2003, 125, 4580-4592.

35. Bagus, P.S.; Hermann, K.; Bauschlicher, C.W., Jr. A new analysis of charge transfer and polarization for ligand-metal bonding: Model studies of AlCO and AlNH. J. Chem. Phys. 1984, 80, doi:10.1063/1.447215.

36. Ganter, B.; Tugendreich, S.; Pearson, C.I.; Ayanoglu, E.; Baumhueter, S.; Bostian, K.A.; Brady, L.; Browne, L.J.; Calvin, J.T.; Day, G.J.; et al. Development of a large-scale chemogenomics database to improve drug candidate selection and to understand mechanisms of chemical toxicity and action. J. Biotechnol. 2005, 119, 219-244.

37. Rozman, K.K.; Doull, J. Dose and time as variables of toxicity. Toxicology 2000, 144, 169-178.

38. Bugrim, A.; Nikolskaya, T.; Nikolsky, Y. Early prediction of drug metabolism and toxicity: Systems biology approach and modeling. Drug Dis. Today 2004, 9, 127-135.

39. Benigni, R.; Tatiana, I.N.; Benfenati, E.; Bossa, C.; Franke, R.; Helma, C.; Hulzebos, E.; Marchant, C.; Richard, A.; Woo, Y.T.; et al. The expanding role of predictive toxicology: An update on the (Q) SAR models for mutagens and carcinogens. J. Environ. Sci. Hea. C 2007, 25, 53-97.

40. Cronin, M.T.D.; Jaworska, J.S.; Walker, J.D.; Comber, M.H.I.; Watts, C.D.; Worth, A.P. Use of QSARs in international decision-making frameworks to predict health effects of chemical substances. Environ. Health Persp. 2003, 111, 1391-1401.

41. Das, B.K.; Mukherjee, S.C. Toxicity of cypermethrin in Labeo rohita fingerlings: Biochemical, enzymatic and haematological consequences. Comp. Biochem. Phys. C 2003, 134, 109-121.

42. Basketter, D.A.; Bremmer, J.N.; Buckley, P.; Kammuller, M.E.; Kawabata, T.; Kimber, I.; Loveless, S.E.; Magda, S.; Stringer, D.A.; Vohr, H.W. Pathology considerations for, and subsequent risk assessment of, chemicals identified as immunosuppressive in routine toxicology. Food Chem. Toxicol. 1995, 33, 239-243.

43. Mukhopadhyay, S.; Mandal, D.; Ghosh, D.; Goldberg, I.; Chaudhury, M. Equilibrium studies in solution involving nickel (II) complexes of flexidentate Schiff base ligands: Isolation and structural characterization of the planar red and octahedral green species involved in the equilibrium. Inorg. Chem. 2003, 42, 8439-8445.

44. Salga, M.S.; Ali, H.M.; Abdulla, M.A.; Abdelwahab, S.I. Gastroprotective activity and mechanism of novel dichlorido-zinc (II)-4-(2-5-methoxybenzylideneamino) ethyl) piperazin-1iumphenolate complex on ethanol-induced gastric ulceration. Chem. Biol. Interact. 2011, in press.

(C) 2012 by the authors; licensee MDPI, Basel, Switzerland. This article is an open access article distributed under the terms and conditions of the Creative Commons Attribution license (http://creativecommons.org/licenses/by/3.0/). 